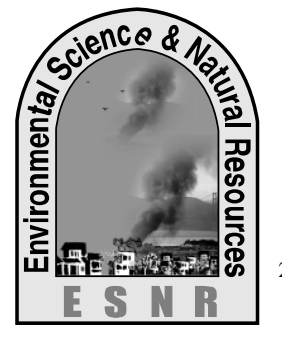

\title{
Breeding Performance, Embryonic and Larval Development of Stinging Catfish, Heteropneustes fossilis in Bangladesh
}

\author{
N. U. Nesa ${ }^{{ }^{*}}$, S. Ahmed ${ }^{2}$ and S. M. Rahman ${ }^{2}$
}

${ }^{1}$ Department of Fisheries Biology and Genetics, Bangladesh Agricultural University, Mymensingh2202, Bangladesh

${ }^{2}$ Fisheries and Marine Resource Technology Discipline, Khulna University, Khulna-9208, Bangladesh

${ }^{*}$ Corresponding author: nurunnesarani@ gmail.com

\begin{abstract}
Considering the threatened status, economic and nutritional importance of stinging catfish (Heteropneustes fossilis), a study on larval development was carried out. Hand stripping method of stinging catfish is being practiced in majority of the hatcheries which is not always felicitous in the sense that puts pressure on brood. The study found that, although fertilization rate was higher in stripping method but non-stripping method was concluded better regarding higher hatching rate. The present study recorded the fertilization and hatching rate in hand stripping and non-striping method $62.33 \pm 4.51,46.67 \pm 5.86$ and $37.33 \pm 2.52,41.33 \pm 5.69$, respectively. Subsequent embryonic developmental mean time for 2-cell, 4-cell, 8-cell, 16-cell, 32- cell, Morula, Blastula, Germinal ring, Gastrula, yolk plug, twisting movement, and just before hatching was $0.21 \pm 0.05,0.39 \pm 0.08,1.12 \pm 0.08,1.28 \pm 0.04,2.09 \pm 0.05,2.23 \pm 0.13,3.58 \pm 0.45$, $5.13 \pm 0.15,7.02 \pm 0.28,8.37 \pm 0.104,15.28 \pm 1.06,20.43 \pm 2.03$ hours, respectively. Results of the current investigation would provide detailed information to the hatchery managers to conduct successful induced breeding strategy of $H$. fossilis as well as other catfishes.
\end{abstract}

Key words: Catfish, Hand-stripping, Non-stripping, Reproduction and Shing

\section{Introduction}

Stinging catfish, Heteropneustes fossilis (Bloch, 1794) is a lucrative high-priced freshwater fish species distributed in South and Southeast Asian countries and aboriginal in Bangladesh, Pakistan, India, Sri Lanka, Nepal, Myanmar, Thailand and Laos (Eschmeyer and Fricke, 2009) and introduced in Iran and Iraq. It is locally known as "Shing" or "Shingi" under the order Siluriformes and family Clariidae. Among the air breathing catfishes, $H$. fossilis is most preferred, highly nourishing and palatable because of its low fat, less spine and high digestibility. Having high medicinal value, it is often recommended for patients after recovery from malaria due to its energizing qualities (Bhuiyan, 1964). It is hardy and amenable to a high stocking rate and utilizes atmospheric oxygen for respiration and thus makes it ideal species for aquaculture. Being an air-breathing catfish can inhabit in a wide variety of habitats including lakes, rivers and often hypoxic waters such as muddy ponds, canals, ditches, swamps and flooded prairies etc. where many fishes cannot thrive. So, this fish can be cultured very easily in any water body.

However, in Bangladesh culture of $H$. fossilis has not yet been flourished due to lack of fry and fingerlings supply in time and difficulty to collect from natural water bodies. To reduce this problem, proper rearing techniques need to be established and information on early embryonic and larval development and organogenesis is of critical importance. The main concern of any seed production and hatchery system is to produce the maximum number of quality fingerlings from the available brood stock for sustainable aquaculture. Hence, to facilitate a steady supply of fingerlings, induction of ovulation and larval rearing techniques are essential. Seed production can be achieved artificially by the induction of spawning via hormone injection using carp pituitary extract (Francis, 1996), human chorionic gonadotropin (Haniffa and Sridhar, 2002), and synthetic GnRHa (Alok et al., 1993;
Vijayakumar et al., 1998; Marimuthu et al., 2000; Haniffa and Sridhar, 2002). Although seed production of $H$. fossilis under hormone administration has been achieved successfully by different authors but this technology is not disseminated to the marginal farmers. A very few hatcheries started to produce fry by hormone administration via stripping method. During stripping, female brood become very weak due to stress. In some cases, immature eggs are released during ovulation that limit the sustainable seed production (e.g., reduced the hatching rates and quality fingerlings). Besides, the gonad can also be destroyed. Thus, the stress can reduce the fecundity of the female in further breeding or it may be infertile or die. Moreover, sperms from $H$. fossilis are unable to collect by stripping which needs to sacrifice the male brood resulting the reduction of male for the next time. Under these circumstances, it is necessary to develop suitable breeding methods to avoid the stress as well as death of brood. So far our knowledge goes, this is the first attempt to produce the fry of $H$. fossilis through induced spawning instead of hand-stripping by which male and female brood can be saved. In this context, the present study illustrated the comparison between striping and non-striping means under laboratory conditions through observing the embryonic and larval development of $H$. fossilis.

\section{Materials and Methods}

\section{Brood selection and collection}

Mature healthy brood were collected from the local market of Khulna and male and female fish were differentiated by observing their genital papillae. In the female, the genital papilla is short, oval and slit-like and protrudes or draws with even the slightest pressure on the abdomen whereas, in male the papilla is conical and elongated with a pointed reddish tip and it never draws in. Immediately after collection, brood were transferred to the hatchery and artificial breeding was conducted in the Batiaghata Upzilla farm hatchery complex. The brood were kept at starving for two or three days in 
two-cemented tank $(3 \times 1.5 \times 1)$ for the acclimatization with sufficient water flow to increase their reproduction response. For this experiment, five males and three females of 60 to $200 \mathrm{~g}$ were selected for semi artificial and artificial method based on the external morphological features according to Marimuthu et al. (2000). Mature male was identified by a slightly pointed genital papilla, and female by a swollen abdomen and a reddish swollen vent. In addition, the maturity of the female was confirmed by pressing slightly in the ventral side of the fish for oozing of eggs. After the selection and acclimatization of the fish they became ready for the breeding. Breeding was performed using commercially available pituitary gland extracts of carp species collected from local market. Then the hormone is administered into the fish body through injection at a single dose for both male $(10 \mathrm{mg}$ $\mathrm{kg}^{-1}$ ) and female (40 $\left.\mathrm{mg} \mathrm{kg}^{-1}\right)$.

\section{Natural spawning / semi artificial breeding}

After injecting the gland extracts, fish were released in the spawning tanks at a rate of $1: 1$. In the tank, continuous water flow was maintained through some shower to stimulate the brood for mating. In this method, the broods released eggs and milt naturally into the tanks.

\section{Artificial hand stripping}

The broods which were used for the artificial breeding were kept into another cemented tank with continuous water flow. After $8-9$ hours of injection, the male and female fish were kept in a different bowl. For breeding the male broods had to sacrifice and the testis was collected. Then the testis was cut into pieces with scissors and mixed with 5\% dextrose and $0.09 \%$ salinity, then screened with thin cloth. Then the female broods were stripped by hand and the eggs were collected.

\section{Fertilization experiment}

The selected sperms were then inseminated with eggs and gently mixed by feathers for 3 to 5 minutes in a small dish. To test the embryonic development, fertilized eggs were washed with fresh water to remove excess milt. Then they were kept on the seed bed in a hatching tray for hatching. The eggs found from the semi-artificial or natural spawning were collected from the bottom of the cemented tank and they were kept on the seed bed on the hatching tray in the separate cemented tank. Just after the mixing of milt with the eggs, they were transferred to the lab for the fertilization and development observation. For the fertilization test eggs were randomly taken for the test. The eggs found from the two-breeding method were taken into separate pots. Then the eggs were kept into three beakers (100 eggs beaker ${ }^{-1}$ ) for each method for the replication of the fertilization. The beaker was kept in the aeration by using aerator. Then eggs from the beaker were taken under the microscope 10 eggs in one slide for counting.

\section{Development timetable}

Development stages of embryos of stinging catfish were observed for each condition continuously after the fertilization until they reached the hatching stage. This study was divided into three stages as seed production, embryonic development and early larval development. The seed production stage starts from the breeding to the count of the fertilization and hatching rate. The embryonic development stage starts from the fertilization and ends with the hatching. The larval stage is characterized by nutritive contribution of the yolk sac and the stage ends when the larva becomes capable of exogenous feeding. The post larval stage begins immediately after absorption of the yolk sac and is characterized by autonomous feeding.

\section{Hatching}

After the embryonic development, the fertilized eggs hatched out within 20 to 25 hours. The hatchlings were examined by microscope. The hatching rates were tested from the beaker in which the eggs of different methods were preserved. For best hatchability, the ambient temperature was kept about $27^{\circ} \mathrm{C}$ to $31^{\circ} \mathrm{C}$ and the $\mathrm{pH}$ was maintained between 7 and 8 . For the hatching, eggs were kept in to the tray on the seed bed. The tray was set up in such a way so that water could easily be removed in the addition of shower water. The water supply was continuously maintained for the oxygen supply, if the water supply stops or becomes very fast the hatch rate will be very poor. During hatching the death eggs, eggs shell and dirt may clog the outlet of the tray. So, care was taken to keep the tray outlet clear. The water depth in the tank and tray were kept $6 \mathrm{~cm}$. On the seed bed, some stones were kept so that the fertilized eggs and hatchling can attach and hide there. The temperature of the water was $29^{\circ} \mathrm{C}, 30^{\circ} \mathrm{C}$, $31^{\circ} \mathrm{C}$ and $\mathrm{P}^{\mathrm{H}}$ was 7.1-8.5.

\section{Results}

The fertilization rate of the stinging catfish for the nonstripping method was $46.67 \pm 5.86$ and for the artificial or hand-stripping method was $62.33 \pm 4.51$ in this study and are shown in Table 1.

Table 1. The fertilization rate of the eggs of different method

\begin{tabular}{lcccc}
\hline $\begin{array}{l}\text { Name of the } \\
\text { method }\end{array}$ & $\mathrm{R}_{1}$ & $\mathrm{R}_{2}$ & $\mathrm{R}_{3}$ & Mean $\pm \mathrm{SD}$ \\
\hline $\begin{array}{l}\text { Semi } \\
\text { artificial }\end{array}$ & 49 & 40 & 51 & $46.67 \pm 5.86$ \\
\hline Artificial & 62 & 58 & 67 & $62.33 \pm 4.51$ \\
\hline
\end{tabular}

Embryonic development

The time taken for each stages of embryonic development are illustrated in Table 2. 
Table 2. The time taken for each stages of embryonic development

\begin{tabular}{lllll}
\hline \multirow{2}{*}{ Stages } & \multicolumn{4}{l}{ Time taken for development } \\
\cline { 2 - 5 } & $\mathrm{R}_{1}$ & $\mathrm{R}_{2}$ & $\mathrm{R}_{3}$ & Mean SD \\
\hline Fertilization & 0 & 0 & 0 & 0 \\
\hline $\begin{array}{l}\text { Two-cell } \\
\text { (minutes) }\end{array}$ & 15 & 22 & 25 & $20.67 \pm 5.1$ \\
\hline Four-cell & 38 & 48 & 31 & $39 \pm 8.54$ \\
\hline Eight-cell & 65 & 70 & 80 & $71.67 \pm 7.6$ \\
& & & & 4 \\
\hline Sixteen-cell & 85 & 93 & 87 & $88.33 \pm 4.1$ \\
& & & & 6 \\
\hline 32-cell & 125 & 135 & 127 & $129 \pm 5.29$ \\
\hline Morula (hours) & 2.2 & 2.0 & 2.35 & $2.20 \pm 0.18$ \\
& 5 & & & \\
\hline Blastula & 3.2 & 3.40 & 4.1 & $3.58 \pm 0.45$ \\
& 5 & & & \\
\hline Blastoderm & 3.4 & 4.0 & 4.15 & \\
& 5 & & & \\
\hline Germinal ring & 5.0 & 5.3 & 5.1 & \\
\hline Gastrula & 6.2 & 6.3 & 6.35 & \\
\hline Yolk-plug & 8.4 & 8.45 & 8.25 & \\
\hline Twisting & 13. & 13.2 & 14.1 & \\
movement & 45 & 5 & 5 & \\
\hline Just before & 18. & 20.3 & 22.5 & \\
hatch & 5 & & & \\
\hline
\end{tabular}

\section{Fertilized egg}

The unfertilized eggs of $H$. fossilis was 1-1.1 mm in diameter (Fig. 1a). The stripped eggs are transparent, spherical in shape, adhesive, brownish green in color and devoid of oil globules. The egg membrane was separated from the rest of the egg by a small perivitelline space. Soon after insemination, the ova began to swell leading to an increase in egg diameter. The size of fertilized eggs ranged between 1.3 to 1.4 $\mathrm{mm}$ (Fig. 1b). One minute after fertilization, the adhesiveness of the egg membrane became more apparent and the eggs adhered to the substratum. Fertilized eggs had a reddish spot (blastodisc) on one pole and readily recognizable with the naked eye.

\section{Formation of embryo}

The first cleavage that divides the blastodisc into two blastomeres occurred within 15-25 min postfertilization and is presented in Fig. 1c. The segmentation was typically discoidal meroblastic. The second cleavage (4 cell stages) appeared 30 to $48 \mathrm{~min}$ after fertilization (Fig. 1d) and the 8-cell stage was noticed within 65 to 80 min post-fertilization (Fig. 1e). The 16- and 32-cell stages were observed at 85 to 95 and 125 to 135 min post-fertilization, respectively (Fig. 1f and Fig. 1g). As successive cleavages occurred, the blastomeres were decreased in size and the morula stage was reached between 2-2.35 hours after fertilization (Fig. 1h). At this stage, the crown of the blastoderm starts spreading over the yolk in the form of a thin layer, and the anterior and posterior ends of the embryo become differentiated. At about 3.25-4.1 hours of fertilization, flattening of the cellular material occurred and the embryo attained the blastula stage (Fig. 1i). After 30 to 38 minutes, the spread of blastoderm was evident and at 5 to 5.3 hours post-fertilization, it was flattened on the top resulting in the formation of the germinal ring (Fig. 1j). The embryonic shield appeared within the next 2.1 hours and by that time more than half a portion of the yolk was invaded and the head and tail ends of the embryo became clearly distinguishable. Gastrulation was in progress at about 6.2 to 6.35 hours after fertilization and the blastopore was evident (Fig. $1 \mathrm{k}$ ). In another $30 \mathrm{~min}$, the yolk invasion was completed and the blastopore was almost closed.

\section{Differentiation of embryo}

Observation made at 8 to 10 hours post-fertilization, revealed that the antero-posterior axis was distinguishable, cephalic portion being broader, and embryonic rudiment became distinct with two somites (Fig. 11). The anterior protuberance formed a head fold and the posterior part elongated to form the tail fold. The maximum size of the coiled embryo now was 0.76 $\mathrm{mm}$ and the eye vesicles were demarcated. About 6-8 somites were formed after 11 to 12 hours and the optic cups were clearly distinguished. In about 12.45 to 13.30 hours from fertilization, more than three fourths of the egg peripherical space was occupied by the embryo and the number of mesodermal somites gradually increased from 8 to 12 and pigmentation was noticed in the somites, and the notochord was more clearly seen and the fore, mid, and hind brain regions were noticed (Fig. $1 \mathrm{~m})$. The cephalic portion was broadened and the embryo was embedded in the yolk mass over all its length. At 16.35 to 17 hours, the embryo occupied the whole space inside the egg, the mesodermal somites ranged from 12-15 in numbers, blood circulation was observed, ectodermal thickening to form the lens of the eye was indicated, the caudal tail region started to detach from the yolk mass, the embryonic fin fold appears, and the Kupffer's vesicle was noticed. Motility in the embryo was observed with 18-20 contractions per minute. In the 18 to 20 hours old embryo, 18-20 somites were observed. The embryonic fin fold on the ventral side extended up to the 11 th somite. The eye lens was fully formed in the eye, and the olfactory placode was indicated.

Blood circulation commenced over the yolk into the rudimentary heart lying anterior to the yolk sac. In the 22-h old embryos, the somite number increased to 2225 and the yolk was completed encircled by the embryo and the tail end was free from the first 2 somites (Fig. 1n). The olfactory pits and auditory vesicles were prominently visible. Melanophores appeared scattered above the neural chord over the trunk and caudal regions. The heartbeat ranged from 170 to 175 per min and the embryo begins to twist itself, continuously beating against the inside of the eggshell by the caudal region, especially around the middle part of the body. 


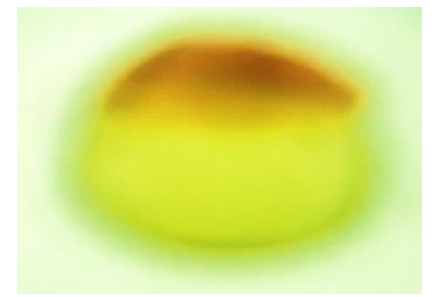

1. a

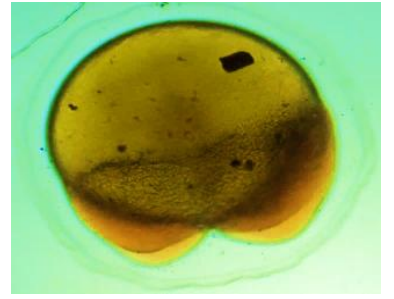

1. d

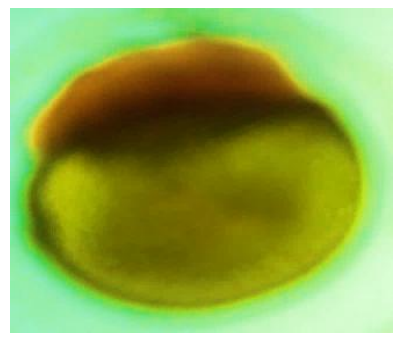

1. $\mathrm{g}$

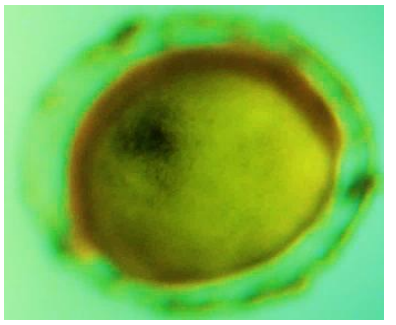

1. $\mathrm{j}$

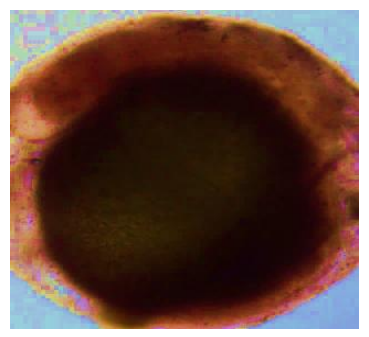

1. $\mathrm{m}$

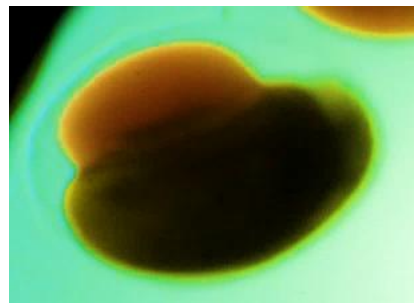

1. $\mathrm{b}$

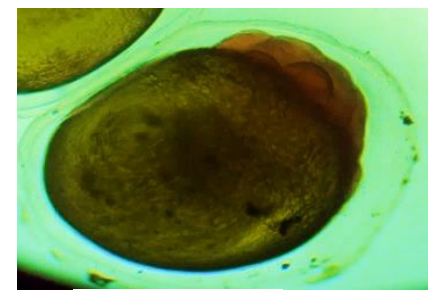

1. $\mathrm{e}$

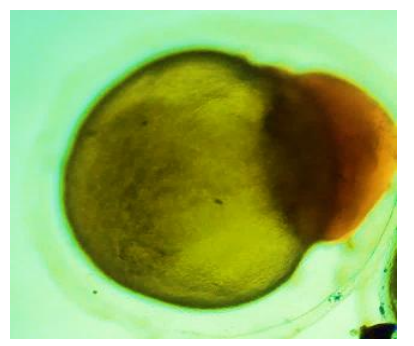

1. $\mathrm{h}$

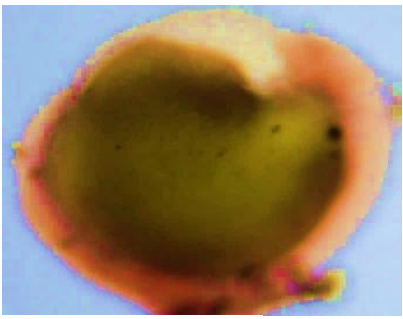

1. $\mathrm{k}$

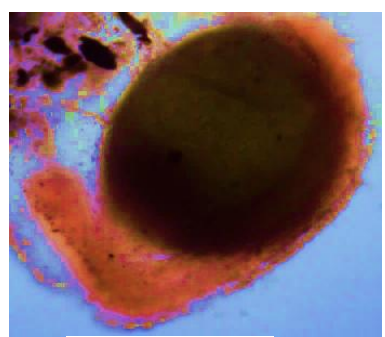

1. $\mathrm{n}$

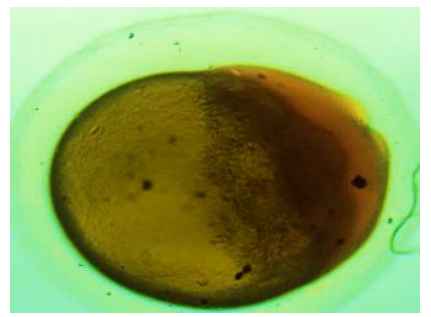

1. c

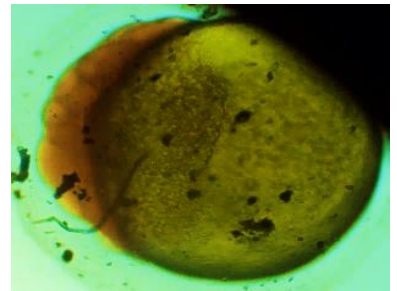

1. $\mathrm{f}$

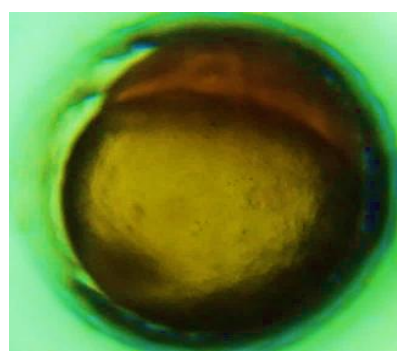

1. $\mathrm{i}$

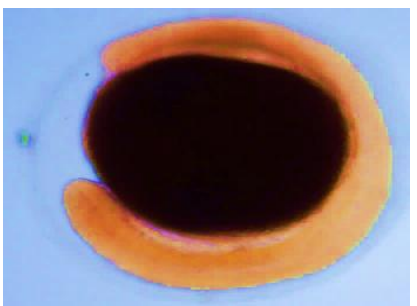

1. 1

Fig. 1. 1. a. unfertilized egg. 1. b. fertilized egg. 1. c. two cell. 1. d. four cell. 1. e. 8 cell. 1. f. 16 cell. 1. g. 32 cell. 1. h. Morula. 1. i. Blastula. 1. j. germinal ring. 1. k. Gastrula. 1. 1. yolk plug. 1. m. twisting movement. 1. n. just before the hatch.

Hatching took place about 23-24 h after fertilization. Before hatching, frequent embryonic twitching movements were observed as the embryo tries to rupture the perivitelline membrane. The middle part of the embryo becomes disconnected from the egg envelop by rupturing the egg capsule. In the successive periods, the egg membrane is broken down from the caudal region and the hatchling emerged from the egg capsule. 


\section{Larval and post larval development}

The hatching rate for the non-stripping method was $41.33 \pm 5.69$ and for the artificial method was $37.33 \pm 2.52$ and are presented in Table 3. The results coincide with the findings of Yadav and Bart (2003) who found that the fry production for the semi artificial or non-stripping method is higher (mean 251) $(\mathrm{P}<0.05)$ compared to artificial one.

Table 3. The rate of hatching of eggs different method

\begin{tabular}{lllll}
\hline $\begin{array}{l}\text { Name of the } \\
\text { method }\end{array}$ & $\mathrm{R}_{1}$ & $\mathrm{R}_{2}$ & $\mathrm{R}_{3}$ & Mean $\pm \mathrm{SD}$ \\
\hline Semi artificial & 46 & 35 & 43 & $41.33 \pm 5.69$ \\
\hline Artificial & 35 & 40 & 37 & $37.33 \pm 2.52$ \\
\hline
\end{tabular}

\section{Hatchling}

The newly hatched larvae were transparent and light brown in color and $2.5 \pm 0.2 \mathrm{~mm}$ in length with a laterally compressed body (Fig. 2a). The hatchlings had unpigmented eyes and were devoid of distinct mouths and fins. Since the head was very small, it was not distinctly separated from the yolk sac. The yolk sac was oval in shape and pale greenish in color. The diameter of yolk sac was $0.65 \mathrm{~mm}$. A functional heart with blood circulation was noticed. The head and the yolk sac appeared together as a bulb-like structure when viewed from above. Two to three hours after hatching, the fin folds were differentiated. A thin membranous fin fold surrounded the caudal region and extended up to the yolk sac. The heart beat was $180 \mathrm{~min}^{-1}$ and the anal fin fold around the tail was continuous. The larvae inhabited the bottom of the tank and swam with rapid movements using their tails.

\section{The 4-h old larva}

The average length of the 4-h old larvae was about $3.2 \pm 0.2 \mathrm{~mm}$ and brownish in color and the mouth has yet to develop (Fig. 2b). The anus invagination was located almost at the mid ventral part of the body. A conspicuous depression identified the position of the mouth and the eyes were un- pigmented. The heart becomes more distinct and is two chambered. Circulation of body fluid was observed around the notochord, in addition to the brain and yolk. A tube emerges from the posterior-dorsal side of the yolk sac which represents the digestive tract. Barbells have not yet been developed at this stage. Blood corpuscles are reddish yellow showing formation of hemoglobin. The pigmentation was dark in the anterior region and melanophores are dispersed in the yolk sac and were present on the unpaired fin. The larvae converged on a group and some of them began to swim.

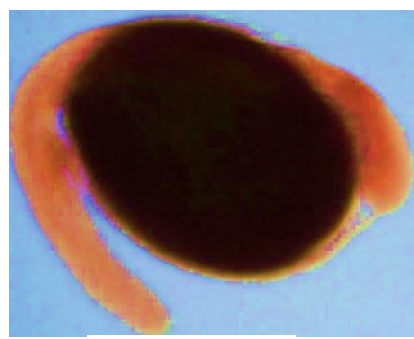

2. a

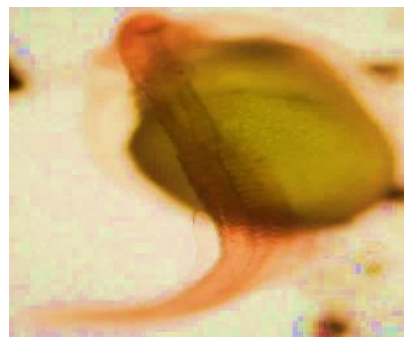

2. d

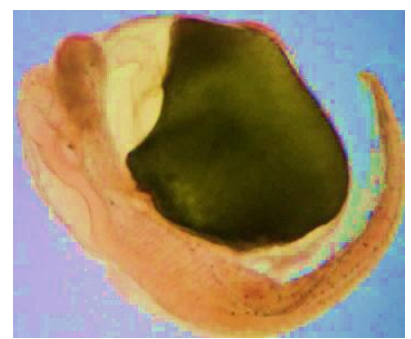

2. $b$

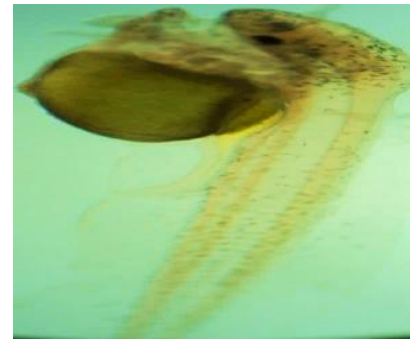

2. e

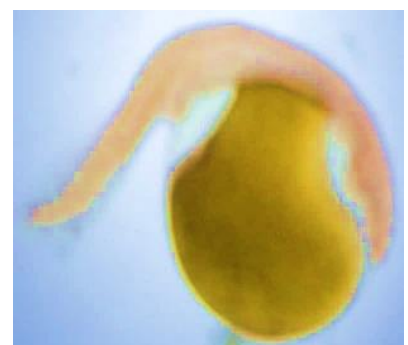

2. c

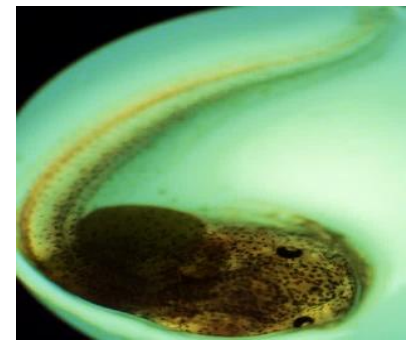

2. $\mathrm{f}$

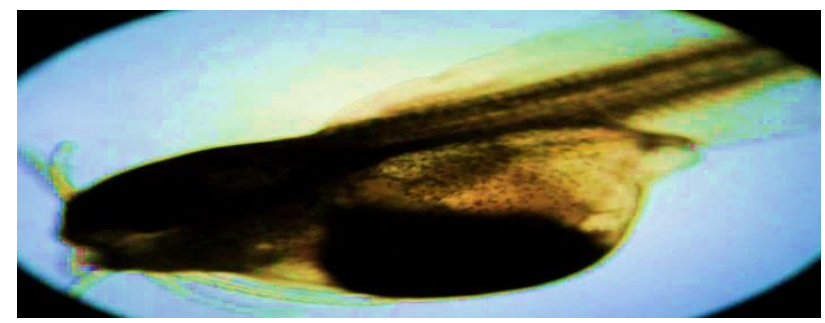

2. $\mathrm{g}$

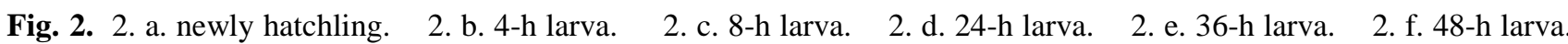
2. g. 3-d larva. 


\section{The 8-h old larva}

The average length of 8 -h old larva was about $3.7 \pm 0.1$ $\mathrm{mm}$ (Fig. 2c). The bulged yolk became gradually elongated at this stage and the buccal invagination was noticed in the anterior region. The larva displayed a dorsoventral unpaired fin, and some melanophores appeared on the head region, ventral side of the notochord and dorsal side of the body. Internal body organs, like the heart and brain, were clearly distinct. Ray like markings was faintly noticeable at the end of the caudal region and circulation was conspicuous in the optic region with some pigments visible on the iris. At this stage, the majorities of the larvae became active and moved to the water surface, and were very sensitive to light.

\section{The 24-h old larva}

The average length of the $24 \mathrm{~h}$ old larva was measured at $4.0 \pm 0.2 \mathrm{~mm}$ with a reduced yolk sac (Fig. 2d). Dark pigmented and prominent eyespot appeared on the anterior part of the head and at this stage 32 myotome were seen. The buccal invagination appeared and it was not connected with the pharyngeal tube. The upper jaw and lower jaws were formed, the pectoral fin buds were seen as a small protuberance, and the alimentary tract was distinct. The mouth was not yet opened at this stage and the anal opening was still closed. The heart was visible in front of the yolk and the blood circulatory system was fully functional. Pigmentation extended to the yolk sac both dorsally and ventrally, whereas melanophores were scattered on the dorsal fin fold and trunk region. Barbells appeared in the form of tiny knobs in 1- d old larvae.

\section{The 36-h old larva}

The 36-h old larva attained an average length of $4.3 \pm 0.3$ $\mathrm{mm}$ (Fig 2e). The eyes were dark pigmented and spherical in shape. The pectoral fin was oval shaped with a membranous flap and actively used for free movement. The heart was clearly visible, located behind the head and showed regular beats. The mouth was formed as a terminal opening and the vent just opened. Rudimentary gill openings and olfactory pits were differentiated and a thick band of melanophores run from the postorbital region to the base of the pectoral and the yolk reserve was further diminished.

\section{The 48-h old larva}

The larva was $4.6 \pm 0.2 \mathrm{~mm}$ in length with a post anal length of $2.4 \mathrm{~mm}$ (Fig. 2f). The eyeball was dark and prominent; the mouth cleft was well formed with a well-developed lower jaw. The barbells became elongated and prominent around the mouth and the yolk reserve had further diminished in size. The pectoral fin had become paddle shaped with an undulating dorsal margin. The anal aperture and opercula were well formed and distinct. The membranous fin fold surrounded the entire area from behind the head region. Blood circulation was observed in the opercula, heart and tail region. Melanophores were more concentrated at the head region than the body. The alimentary canal became short, straight and distinct, and the larva started feeding exogenously and a pouch like stomach was formed.

\section{The 3-d old larva}

The larva reached an average length of $5.0 \pm 0.2 \mathrm{~mm}$ with a post anal length of $2.7 \mathrm{~mm}$ (Fig. $2 \mathrm{~g}$ ). The body was brownish in color and the mouth and anus became fully functional. The size of the stomach was larger than the intestine and the intestine was convoluted ventrally to the stomach. The pectorals, which were seen to move vigorously, had been vascularized with a distinct circular vessel running across them. The head was prominent and free movement of the eyeball was observed and four pairs of barbells were noticed at this stage. The size of the barbells had slightly increased since the previous stage. The eyes were further differentiated and pigmentation had appeared around the head and snout. The reserved yolk material had been completely absorbed. The abdomen appeared as heart shaped when viewed from the ventral side, and blood circulation was observed in the opercula, heart and tail regions. The caudal fin had 5 rudimentary rays and the pectoral fins were vascularized. Pigments were more concentrated in the anterior region; however, the density had decreased gradually. The larvae exhibited vigorous movements to the water surface and occasionally sink to the bottom. At this stage, the shoaling behavior of the larvae was observed.

\section{Discussion}

At present, Bangladeshi people are solely dependent on the natural or open water sources for fry and fingerlings of stinging catfish, but the natural sources alone cannot supply adequate amount for commercial aquaculture. Therefore, the breeding of the fish was carried out by using carp pituitary gland extraction and the dose used was same as for the walking catfish (Clarias batrachus), $40 \mathrm{mg}$ for female and $10 \mathrm{mg}$ for male. Furthermore, to expand the aquaculture of stinging catfish, knowledge of early larval development and feeding is imperative. But the information regarding embryonic and larval development of this fish is scanty and only few studies have ever been made; therefore, the present study was conducted.

The diameters of unfertilized eggs ranged from 1 to 1.1 $\mathrm{mm}$ and fertilized eggs $1.3-1.4 \mathrm{~mm}$, which is similar to those observed by Thakur et al. (1974) (1.4-1.6 mm) and Marimuthu et al. (2009) (1.3-1.5 mm). This might be related to the existence of different strains, conditions, and size of the female in the wild conditions (Thakur, 1980). Alternatively, it may also depend on the individual parental investment, moderated by the food availability experienced by the female fish to induce and spawn eggs. The fertilized eggs of $H$. fossilis were adhesive like other catfish species, representing an adaptation to prevent the flowing of the eggs in the water currents and provide optimal oxygen supply. The mode of cleavage recorded in the present observation was same to other catfish species such as Pangasius sutchi (Islam, 2005) and Mystus montanus (Arockiaraj et al., 2003). 
First and second cleavage occurred within 15-25 min and 30-38 min respectively, and the 8-, 16- and 32-cell stages were noticed at 65 to 80,85 to 95 and 125 to 135 min post-fertilization, respectively. Likewise, Marimuthu et al. (2000), the first cleavage occurred within 15-20 min and the 16-cell stage was reached in $90 \mathrm{~min}$ of post-fertilization. Thakur et al. (1974) observed that the first cleavage, 16-cell, and morula stages in $H$. fossilis were attained within 30, 70-80 and $100 \mathrm{~min}$, respectively after fertilization. The morula stage was reached between 2-2.35 hours after fertilization. At about 3.25-4.1 hours of fertilization, the embryo attained the blastula stage. At 5 to 5.3 hours post-fertilization, it was flattened on the top resulting in the formation of the germinal ring. Gastrulation was in progress at approximately 6.2 to 6.35 hours after fertilization. Marimuthu et al. (2000), reported that the morula stage in 140 min of post fertilization (Kim et al., 1987). The morula stage in Indian major carps was known to be reached within 2-3.5 h after fertilization (Chondar, 1994). Marimuthu et al. (2000), reported that the gastrula stage was reached in $7 \mathrm{~h}$ after fertilization. Banerji (1974), and Munshi and Hughes (1991) reported that in $C$. punctatus, the blastula stage appeared after 2-3 $\mathrm{h}$ and the yolk invasion was completed at $9 \mathrm{~h}$ after fertilization. In A. testudineus, the invasion of the yolk by the blastoderm was completed at about $10 \mathrm{~h}$ after spawning (Munshi and Hughes, 1991). Before 2-2.5 hour of hatching the embryo developed to twisting movement stage. Marimuthu et al. (2000), found in their study just $1-2 \mathrm{~h}$ before hatching, the embryo of $H$. fossilis showed twisting movements inside the eggshells. The similar hatching behavior is reported in the same fish by Thakur et al. (1974), and commonly observed in other catfish species, C. batrachus (Thakur, 1980) and P. sutchi (Islam, 2005).

The observation of early development and pre-hatching behavior of embryo in $H$. fossilis agrees well with the results obtained in C. gariepinus (Bruton, 1979; Zaki and Abdula, 1983; Herath, 1988) and in M. montanus (Arockiaraj et al., 2003). In the present study, the hatching time taken 20 to 24 hours but Marimuthu et al. (2000), found the required time for hatching 23 to 24 . This study was conducted at $30 \pm 2{ }^{\circ} \mathrm{C}$ temperature, whereas Marimuthu et al. (2000), carried out their work at $29^{\circ} \mathrm{C}$. The temperature has a significant effect on the embryonic development. Kohli and Vidyarthi (1990) reported the incubation period of 16-18 $\mathrm{h}$ in $\mathrm{H}$. fossilis at a temperature of $26^{\circ} \mathrm{C}$. Ramanathan et al. (1985) outlined the incubation period in Mystus punctatus (Jerdon) to be varied from 18-24 h at a temperature of $28.5 \pm 1.8^{\circ} \mathrm{C}$. Banerji (1974) found that the hatching of Channa punctatus occurred in $24 \mathrm{~h}$ at a temperature of $28^{\circ} \mathrm{C}$. Munshi and Hughes (1991) reported the incubation period in A. testudineus was about $10.5 \mathrm{~h}$ after fertilization. Zaki and Abdula (1983) and Herath (1988) reported shorter incubation periods at higher temperatures. The development and incubation periods of embryo in most fishes are totally temperature dependent and vary from one species to another (De Graaf and Janssen, 1996).

In the present investigation, it was found that the mouth was opened at $36 \mathrm{~h}$ after hatching. But in H. longifils, Ogunji and Rahe (1999) reported the mouth opening at 3-4 $\mathrm{h}$ after post-hatching. Hatchling of $H$. fossilis commenced feeding at $48 \mathrm{~h}$, whereas Ogunji and Rahe (1999) reported the first feeding in H. longifilis larvae at $48 \mathrm{~h}$ after hatching. The complete yolk sac absorption of $H$. fossilis was observed on the 3-d when the larvae gained an average length of $5.0 \pm 0.2 \mathrm{~mm}$. Complete disappearance of the yolk materials was observed on the 3-d in C. striatus (Alikunhi, 1953), Clarias lazera (Valenciennes) (Pan and Zheng, 1987), and in Mystus macropterus (Bleeker) (Wang et al., 1992). The yolksac of $H$. longifilis was found to be completely reabsorbed at $55 \mathrm{~h}$ after hatching (Ogunji and Rahe, 1999).

\section{Conclusions}

The present study demonstrates that hatching rate in non-stripping method was higher though the fertilization rate was higher in hand-stripping method. Therefore, non-stripping was found the more effective method for the hatchery breeding of stinging catfish. Embryonic and larval development stages are the most delicate part of their life cycle and resulting in mass mortality due to unavailability of appropriate husbandry. So, information on early development of $H$. fossilis generated from our study will help sustainable development of aquaculture as well as management strategy to protect this indigenous species from being extinct.

\section{References}

Alikunhi, K. H. 1953. Notes on the bionomics, breeding and growth of the murrel Ophiocephalus striatus (Bloch). Proceedings of the Indian Academy of Sciences, 38: 10-20.

Alok, D.; Krishnan, T.; Talwar, G. P. and Garg, L. C. 1993. Induced spawning of catfish, Heteropneustes fossilis (Bloch), using D-Lys salmon gonadotropin releasing hormone analog. Aquaculture, 115: 159-167.

Arockiaraj, A. J.; Haniffa, M. A.; Seetharaman, S. and Sing, S. P. 2003. Early Development of a Threatened Freshwater Catfish Mystus montanus (Jerdon). Acta Zoologica Taiwanica, 14: 23-32.

Banerji, S. R. 1974. Hypophysation and life history of Channa punctatus (Bloch). Journal of the Inland Fisheries Society of India, 6: 62-73.

Bhuiyan, A. L. 1964. Fishes of Dacca. Asiatic Society of Pakistan, Dacca. 148 p.

Bloch, M. E. 1794. Naturgeschicht der ausländischen Fische. Mit sechs und dreissig ausgemalten Kupfern nach Originalen. Achter Theil. Berlin. IIV, 1-174 p.

Bruton, M. N. 1979. The breeding and early development of Clarias gariepinus (Pisces: Clariidae) in lake sibaya South Africa, with a review of breeding in species of the subgenus 
Clarias (Clarias). Transactions of the Zoological Society of London, 35: 1-45.

Chondar, S. L. 1994. Induced Carp Breeding. $3^{\text {rd }}$ Edition, CBS Publishers and Distributors, New Delhi, India. $142 \mathrm{p}$.

De Graaf, G. J. and Janssen, H. 1996. Artificial reproduction and pond rearing of the African catfish Clarias gariepinus in sub Saharan Africa. FAO Fisheries Technical Papers, 362, 1-73. ftp://ftp.fao.org/docrep/fao/003/w3595e/w3595e00 .pdf

Eschmeyer, W. N. and Fricke, R. 2009. Catalog of Fishes, electronic version (updated 13 March 2009). Retrieved from http://research.calacademy.org/ichthyology/catalo g/fishcatsearch.html

Francis, T. 1996. Studies on the effect of pituitary hormones and feeds on the reproduction of Heteropneustes fossilis (Bloch) (PhD Thesis). Tamil Nadu Veterinary and Animal Sciences University, Madras, India.

Haniffa, M. A. and Sridhar, S. 2002. Induced spawning of spotted murrel (Channa punctatus) and catfish (Heteropneustes fossilis) using human chorionic gonadotropin and synthetic hormone (ovaprim). Veterinarski Arhiv, 72(1): 51-56.

Herath, H. K. S. 1988. Hybridization, early development of embryos and production characteristics of larvae of African Catfish Clarias gariepinus (Burchell) and Asian catfish Clarias batrachus (Linnaeus) (Master Thesis). Wageningen Agricultural University, Wageningen, Netherlands.

Islam, A. 2005. Embryonic and larval development of Thai pangas (Pangasius sutchi Fowler 1937). Development, Growth and Differentiation, 47: 1-6.

Kim, Y. U.; Park, Y. S. and Kim, D. S. 1987. Development of eggs, larvae and juveniles of loach, Misgurnus mizolepis, Gunther. Bulletin of the Korean Fisheries Society, 20: 6-23.

Kohli, M. S. P. and Vidyarthi, S. 1990. Induced breeding embryonic and larval development in Heteropneustes fossilis (Bloch) in the agroclimatic conditions of Maharastra. Journal of the Indian Fisheries Association, 20: 15-19.

Marimuthu, K.; Haniffa, M. A. and Aminur, R. M. 2009. Spawning performance of native threatened spotted snakehead fish, Channa punctatus (Actinopterygii: Channidae: Perciformes), induced with Ovatide. Acta Ichthyologica Et Piscatoria, 39(1): 1-5.

Marimuthu, K.; Muruganandam, M.; Arockiaraj, A. J. and Haniffa, M. A. 2000. Induced spawning of the Indian catfish Heteropneustes fossilis (Singhi) using a synthetic hormone ovatide. Fishing Chimes, 19: 105-106.

Munshi, J. S. D. and Hughes, G. M. 1991. Air breathing fishes of India. Oxford and IBH Publishing, New Delhi, India.

Ogunji, J. O. and Rahe, R. E. 1999. Larval development of the African catfish Heterobranchus longifilis VAL, 1840 (Teleostei; Claridae) and its larval behavior. Journal of Aquaculture in the Tropics, 14: 11-25.

Pan, J. H. and Zheng, W. B. 1987. Observations on the embryonic and larval development of Clarias lazera. Journal of South China Normal University Natural Science, 1: 19-27.

Ramanathan, N.; Natarajan, P. and Sukumaran, N. 1985. Studies on the induced spawning and larva rearing of a fresh water catfish Mystus punctatus (Jerdon). Proceedings of Indian Academy of Sciences (Animal Science), 94: 389-398.

Thakur, N. K. 1980. Notes on the embryonic and larval development of an air-breathing catfish Clarias batrachus (Linn). Journal of the Inland Fisheries Society of India, 12: 30-43.

Thakur, N. K.; Pal, R. N. and Khan, H. A. 1974. Embryonic and larval development of Heteropneustes fossilis (Bloch). Journal of the Inland Fisheries Society of India, 6:33-44.

Vijayakumar, C.; Sridhar, S. and Haniffa, M.A. 1998. Low cost breeding and hatching techniques of the catfish (Heteropneustes fossilis) for small-scale farmers. Naga, 21: 15-17.

Wang, D. S.; Zhang, Y. G. and Luo, Q. S. 1992. Observations on the larval development of Mystus macropterus (Bleeker) Bagridae. Journal of Fish Biology, 40:371-379.

Yadav, C. N. R. and Bart, A. N. 2003. Hatchery Breeding of Catfish, Heteropneustes fossilis (Bloch) in Nepal. Journal of the Institute of Agriculture and Animal Science, 24: 59-66.

Zaki, M. I. and Abdula, A. 1983. The reproduction and development of Clarias gariepinus (Claridae) from Lake Manzala (Egypt). Journal of Ichthyology, 23: 48-58. 